\title{
Effect of Inclusion of Dried Garlic (Allium sativum) Powder in the Diet on Serum Biochemical Profile of Japanese Quail
}

\author{
M. Durga Bhavani ${ }^{1}$, D. Srinivas Kumar ${ }^{1 *}$, K. Raja Kishore ${ }^{1}$ and K. Naga Raja Kumari ${ }^{2}$ \\ ${ }^{1}$ Department of Animal Nutrition, NTR College of Veterinary Science, Gannavaram, INDIA \\ ${ }^{2}$ Department of Poultry Science, NTR College of Veterinary Science, Gannavaram, INDIA \\ "Corresponding author: DS Kumar; E-mail: kumardhulipalla@gmail.com
}

Accepted: 01 Dec., $2020 \quad$ Revised: 12 Jan., $2021 \quad$ Accepted: 18 Jan., 2021

\begin{abstract}
An investigation is carried out to study the effect of inclusion of dried garlic powder at varying levels on serum biochemical profile of Japanese quails. One hundred and fifty, day old quail chicks distributed randomly to five dietary groups each with three replicates of ten quails and were offered broiler quail diets (starter and finisher) to meet the nutrient requirements (ICAR, 2013). During the experiment, dried garlic powder is included at $0.0 \%\left(\mathrm{~T}_{1}\right.$ : Control), $0.50 \%\left(\mathrm{~T}_{2}\right), 1.0 \%\left(\mathrm{~T}_{3}\right), 1.5 \%\left(\mathrm{~T}_{4}\right)$ and $2.0 \%$ $\left(\mathrm{T}_{5}\right)$ level by marginal adjustment of other feed ingredients. All the rations were made iso-caloric and iso-nitrogenous. Results indicated that the serum total protein $(\mathrm{P}<0.05)$, HDL-C and phosphorous $(\mathrm{P}<0.01)$ contents increased while serum glucose, triglycerides, total cholesterol, LDL-C, VLDL-C and creatinine levels decreased $(\mathrm{P}<0.01)$ with increase in the level of inclusion of dried garlic powder from 0 to $2.0 \%$ in the diet. However, inclusion of dried garlic powder up to $2.0 \%$ in the diet had no effect $(\mathrm{P}>0.05)$ on serum albumin, globulin and calcium levels. The study indicated that dried garlic powder can be incorporated up to $2.0 \%$ level in the diet as natural feed additive for production of low cholesterol meat without any adverse effect on performance of quails.
\end{abstract}

\section{HIGHLIGHTS}

(0 Inclusion of Garlic as feed additive significantly decreased the cholesterol content in meat.

(0 Serum creatinine content decreased with inclusion of Garlic in the diet.

Keywords: Cholesterol, Glucose, Total Protein, Triglycerides, Quail

Feeding strategies viz. use of antibiotic feed additives, low protein diets etc. adopted in broilers for decreasing the cost of production had resulted in high carcass fat. Feeding diets with high cholesterol and saturated fats from animal products will result in increased plasma total cholesterol and low-density lipoprotein (LDL) cholesterol (Mayo, 1997). Elevated blood cholesterol and triacylglycerol are associated with increased risk of cardiovascular disease. Use of medicinal herbs and spices as natural feed additives can reduce levels of serum cholesterol, triacylglycerol and abdominal fat in broiler chicken. One such medicinal herb with significant lipid lowering action is garlic.

Garlic (Allium sativum), the spices of life is unique among the members of plant kingdom. Several clinical reports, including meta-analysis have revealed that garlic possess several beneficial effects viz. anti-microbial, antioxidant (Prasad et al., 2009), anti-hypersensitive, hypo-cholesterolemic (Puvaca et al., 2014) effects in both humans and animals. These functions were mainly attributed to the bioactive components of garlic such as alliin, diakylpolysulphides and allicin (Canogullari et al., 2010). Several studies were conducted in broilers (Ademola et al., 2009; Stanacev et al., 2012; Puvaca et al., 2014) to study the effect of garlic on blood biochemical

How to cite this article: Bhavani, M.D., Kumar, D.S., Kishore, K.R. and Kumari, K.N.R. (2021). Effect of inclusion of dried garlic (Allium sativum) powder in the diet on serum biochemical profile of Japanese quail. $J$. Anim. Res., 11(1): 81-87.

Source of Support: None; Conflict of Interest: None 
profile while very scanty literature is available in quails (Canogullari et al., 2010). Hence, the present investigation was conducted to study the effect of inclusion of garlic at varying levels in the diet on serum biochemical profile of Japanese quail.

\section{MATERIALS AND METHODS}

The present investigation is carried out at Poultry Experimental Station attached to Livestock Farm Complex, NTR College of Veterinary Science, Gannavaram, India.

\section{Experimental design}

One hundred and fifty, day old Japanese quail chicks obtained from a local hatchery were utilized in the experiment. Quail chicks were wing banded and weighed individually. All chicks were divided into five treatments. Each treatment contained three replicates with ten chicks per replicate allotted at random. The experiment was conducted for 5 weeks duration.

\section{Preparation of experimental diets}

Broiler quail starter and finisher diets (Table 1) were prepared to meet the nutrient requirements (ICAR, 2013). During different phases of the trial, experimental diets were prepared by including dried garlic powder (GP) at $0 \%\left(\mathrm{~T}_{1}\right.$; Control), 0.5\% $\left(\mathrm{T}_{2}\right), 1.0 \%\left(\mathrm{~T}_{3}\right), 1.5 \%\left(\mathrm{~T}_{4}\right)$ and $2.0 \%\left(\mathrm{~T}_{5}\right)$ levels. All the diets were made iso-caloric and iso-nitrogenous.

\section{Management and feeding}

All the chicks were housed in battery brooders throughout the experiment. All the cages were provided with uniform brooding facilities, feeders and waterers. Irrespective of the treatments, all the chicks were fed ad-libitum 2 times a day with respective broiler quail starter diet from 0-3 weeks and finisher diet from 4-5 weeks of age. Fresh and clean drinking water was made available at all the time.

\section{Blood collection}

At the end of study period ( $5^{\text {th }}$ week), two birds per replicate and thus a total 6 birds per treatment were randomly selected, weighed and slaughtered. At the time of slaughter, blood samples were collected from each bird to determine serum biochemical parameters using diagnostic kits (M/s. Span Diagnostics Private Limited).

\section{Statistical analysis}

All the data were analyzed statistically (SPSS, $17^{\text {th }}$ Version) as per Snedecor and Cochran (1994) and comparison of means was done using Duncan's multiple range tests (Duncan, 1955).

\section{RESULTS AND DISCUSSION}

The ingredient and chemical composition of quail starter and finisher diets formulated by incorporating dried garlic powder at varying levels and fed to Japanese quails is shown in Table 1. Iso-nitrogenous and iso-caloric diets were formulated using maize, DORB, soybean meal, fish meal and dried garlic powders as per ICAR (2013) specifications. The chemical composition of dried garlic powder used in the present study was $86.9,97.12,16.50$, $3.10,2.10,75.42,2.88,0.46,13.29$ and 5.54 per cent for DM, OM, CP, EE, CF, NFE, TA, AIA, Ca and P, respectively.

\section{Effect on serum total protein}

The serum total protein content $(\mathrm{mg} / \mathrm{dl})$ of quails increased significantly $(\mathrm{P}<0.05)$ with increased levels of dried garlic powder from 0 to $2.0 \%$ in the diet (Table 2). It is reported that dried garlic powder has anti-microbial, anti-fungal effects and contain anti-oxidants that decrease lipid oxidation (Canogullari et al., 2010) which might have enhanced the immune system resulting in increased serum total protein concentration in quails. These results corroborated with the findings of Shamsa et al. (2013) who reported increased $(\mathrm{P}<0.05)$ serum total protein concentration in broilers upon feeding diets containing 4\% garlic. Similarly, Brzoska et al. (2015) also reported significantly $(\mathrm{P}<0.01)$ higher serum total protein upon adding liquid garlic extract at $2.25 \mathrm{ml} / \mathrm{kg}$ in broiler diet. However, many researchers reported that feeding of garlic in the diet had no effect $(\mathrm{P}>0.05)$ on serum total protein in broilers (Yalcin et al., 2006; Ao et al., 2010; Fadlalla et al., 2010) and laying hens (Motamedi and Taklimi, 2014). 
Table 1: Ingredient (\%) and Chemical composition (\% DM basis) of quail diets

\begin{tabular}{lllllllllll}
\hline & \multicolumn{9}{c}{ Starter Diet } & \multicolumn{5}{c}{ Finisher Diet } \\
\hline Constituent/ Diet & $\mathbf{T}_{1}$ & $\mathbf{T}_{2}$ & $\mathbf{T}_{3}$ & $\mathbf{T}_{4}$ & $\mathbf{T}_{5}$ & $\mathbf{T}_{1}$ & $\mathbf{T}_{2}$ & $\mathbf{T}_{3}$ & $\mathbf{T}_{4}$ & $\mathbf{T}_{5}$ \\
\hline Maize & 49.0 & 48.9 & 48.7 & 48.5 & 48.4 & 57.50 & 57.40 & 57.20 & 57.10 & 56.90 \\
DORB & 7.30 & 6.90 & 6.70 & 6.40 & 6.10 & 7.50 & 7.10 & 6,90 & 6.50 & 6.30 \\
Soybean meal & 36.30 & 36.30 & 36.20 & 36.20 & 36.10 & 27.40 & 27.40 & 27.30 & 27.30 & 27.20 \\
Fish meal & 5.00 & 5.00 & 5.00 & 5.00 & 5.00 & 5.00 & 5.00 & 5.00 & 5.00 & 5.00 \\
Dried Garlic Powder & 0.00 & 0.50 & 1.00 & 1.50 & 2.00 & 0.00 & 0.50 & 1.00 & 1.50 & 2.00 \\
DCP & 0.30 & 0.30 & 0.30 & 0.30 & 0.30 & 0.50 & 0.50 & 0.50 & 0.50 & 0.50 \\
Shell grit & 1.20 & 1.20 & 1.20 & 1.20 & 1.20 & 1.20 & 1.20 & 1.20 & 1.20 & 1.20 \\
Salt & 0.25 & 0.25 & 0.25 & 0.25 & 0.25 & 0.25 & 0.25 & 0.25 & 0.25 & 0.25 \\
Trace min mix & 0.15 & 0.15 & 0.15 & 0.15 & 0.15 & 0.15 & 0.15 & 0.15 & 0.15 & 0.15 \\
Feed additives & 0.50 & 0.50 & 0.50 & 0.50 & 0.50 & 0.50 & 0.50 & 0.50 & 0.50 & 0.50 \\
\hline Total & 100 & 100 & 100 & 100 & 100 & 100 & 100 & 100 & 100 & 100 \\
\hline ME* kcal/kg & 2900.0 & 2902.6 & 2903.5 & 2904.9 & 2906.9 & 2949.4 & 2952.0 & 2952.9 & 2955.4 & 2956.3 \\
\hline CP $(\%)$ & 24.99 & 25.01 & 25.00 & 25.02 & 25.00 & 21.49 & 21.50 & 21.49 & 21.50 & 21.49 \\
\hline Feed cost / 1000 kg (₹) & 25958 & 26288 & 26591 & 26918 & 27224 & 24015 & 24345 & 24648 & 24978 & 25281 \\
\hline
\end{tabular}

Table 2: Effect of dietary inclusion of dried garlic powder at varying levels on serum biochemical profile in Japanese quail

\begin{tabular}{|c|c|c|c|c|c|c|c|c|c|c|}
\hline Treatment & $\begin{array}{l}\text { Total } \\
\text { protein } \\
(\mathrm{g} / \mathrm{dl})\end{array}$ & $\begin{array}{l}\text { Albumin } \\
\text { (g/dl) }\end{array}$ & $\begin{array}{l}\text { Globulin } \\
\text { (g/dl) }\end{array}$ & $\begin{array}{l}\text { Glucose } \\
\text { (mg/dl) }\end{array}$ & $\begin{array}{l}\text { Tri- } \\
\text { glycerides } \\
\text { (mg/dl) }\end{array}$ & $\begin{array}{l}\text { Total } \\
\text { cholesterol } \\
(\mathrm{mg} / \mathrm{dl})\end{array}$ & $\begin{array}{l}\text { HDL } \\
\text { cholesterol } \\
(\mathrm{mg} / \mathrm{dl})\end{array}$ & $\begin{array}{l}\text { LDL } \\
\text { cholesterol } \\
(\mathrm{mg} / \mathrm{dl})\end{array}$ & $\begin{array}{l}\text { VLDL } \\
\text { cholesterol } \\
(\mathrm{mg} / \mathrm{dl})\end{array}$ & $\begin{array}{l}\text { Creatinine } \\
(\mathrm{mg} / \mathrm{dl})\end{array}$ \\
\hline $\mathrm{T}_{1}$ & $\begin{array}{l}3.54^{\mathrm{a}} \pm \\
0.19\end{array}$ & $\begin{array}{l}2.39 \pm \\
0.01\end{array}$ & $1.56 \pm 0.01$ & $\begin{array}{l}233.38^{\mathrm{d}} \pm \\
3.20\end{array}$ & $\begin{array}{l}143.69^{\mathrm{e}} \pm \\
0.68\end{array}$ & $\begin{array}{l}214.22^{\mathrm{d}} \pm \\
0.62\end{array}$ & $\begin{array}{l}128.23^{\mathrm{a}} \pm \\
1.59\end{array}$ & $\begin{array}{l}51.99^{c} \pm \\
0.64\end{array}$ & $\begin{array}{l}28.87^{\mathrm{d}} \pm \\
0.06\end{array}$ & $\begin{array}{l}0.73^{c} \pm \\
0.03\end{array}$ \\
\hline $\mathrm{T}_{2}$ & $\begin{array}{l}3.67^{\mathrm{ab}} \pm \\
0.13\end{array}$ & $\begin{array}{l}2.49 \pm \\
0.02\end{array}$ & $1.62 \pm 0.02$ & $\begin{array}{l}222.36^{\mathrm{c}} \pm \\
2.36\end{array}$ & $\begin{array}{l}137.73^{\mathrm{d}} \pm \\
0.93\end{array}$ & $\begin{array}{l}205.50^{\mathrm{c}} \pm \\
1.52\end{array}$ & $\begin{array}{l}130.60^{\mathrm{ab}} \pm \\
1.32\end{array}$ & $\begin{array}{l}45.69^{\mathrm{b}} \pm \\
1.50\end{array}$ & $\begin{array}{l}27.55^{\mathrm{c}} \pm \\
0.19\end{array}$ & $\begin{array}{l}0.69^{b c} \pm \\
0.02\end{array}$ \\
\hline $\mathrm{T}_{3}$ & $\begin{array}{l}3.84^{\mathrm{abc}} \pm \\
0.16\end{array}$ & $\begin{array}{l}2.60 \pm \\
0.01\end{array}$ & $1.68 \pm 0.01$ & $\begin{array}{l}211.82^{b} \pm \\
3.03\end{array}$ & $\begin{array}{l}131.58^{\mathrm{c}} \pm \\
1.37\end{array}$ & $\begin{array}{l}198.06^{\mathrm{b}} \pm \\
1.71\end{array}$ & $\begin{array}{l}133.76^{\mathrm{bc}} \pm \\
0.59\end{array}$ & $\begin{array}{l}42.72^{b} \pm \\
1.03\end{array}$ & $\begin{array}{l}26.59^{b} \pm \\
0.13\end{array}$ & $\begin{array}{l}0.64^{\mathrm{abc}} \pm \\
0.02\end{array}$ \\
\hline $\mathrm{T}_{4}$ & $\begin{array}{l}4.06^{b c} \pm \\
0.07\end{array}$ & $\begin{array}{l}2.68 \pm \\
0.01\end{array}$ & $1.70 \pm 0.01$ & $\begin{array}{l}202.51^{\mathrm{ab}} \pm \\
3.45\end{array}$ & $\begin{array}{l}126.53^{b} \pm \\
0.36\end{array}$ & $\begin{array}{l}195.47^{\mathrm{b}} \pm \\
0.93\end{array}$ & $\begin{array}{l}136.02^{\mathrm{cd}} \pm \\
0.98\end{array}$ & $\begin{array}{l}39.14^{\mathrm{a}} \pm \\
1.30\end{array}$ & $\begin{array}{l}25.31^{\mathrm{a}} \pm \\
0.07\end{array}$ & $\begin{array}{l}0.60^{\mathrm{ab}} \pm \\
0.05\end{array}$ \\
\hline $\mathrm{T}_{5}$ & $\begin{array}{l}4.16^{\mathrm{c}} \pm \\
0.14\end{array}$ & $\begin{array}{l}2.71 \pm \\
0.13 \\
\end{array}$ & $1.73 \pm 0.01$ & $\begin{array}{l}197.71^{\mathrm{a}} \pm \\
3.30\end{array}$ & $\begin{array}{l}123.24^{\mathrm{a}} \pm \\
0.58\end{array}$ & $\begin{array}{l}191.18^{\mathrm{a}} \pm \\
0.82\end{array}$ & $\begin{array}{l}138.22^{\mathrm{d}} \pm \\
0.96\end{array}$ & $\begin{array}{l}37.06^{\mathrm{a}} \pm \\
0.92\end{array}$ & $\begin{array}{l}24.92^{\mathrm{a}} \pm \\
0.22\end{array}$ & $\begin{array}{l}0.55^{\mathrm{a}} \pm \\
0.02\end{array}$ \\
\hline SEM & 0.08 & 0.05 & 0.04 & 3.67 & 2.01 & 2.22 & 1.05 & 1.47 & 0.39 & 0.02 \\
\hline SS & $*$ & NS & NS & $* *$ & $* *$ & $* *$ & $* *$ & $* *$ & $* *$ & $* *$ \\
\hline
\end{tabular}

Values in column bearing different super scripts differ significantly $*(\mathrm{P}<0.05) * *(\mathrm{P}<0.01)$.

\section{Effect on serum albumin}

Inclusion of dried garlic powder up to $2 \%$ in the diet had no effect $(\mathrm{P}>0.05)$ on serum albumin content $(\mathrm{mg} / \mathrm{dl})$ of quails (Table 2). Corroborating the results of the present study, Fadlalla et al. (2010) reported that feeding graded levels of garlic up to $0.6 \%$ level in the diet of broilers had no effect $(\mathrm{P}>0.05)$ on serum albumin content. Ao et al. (2010) in laying hens and Onu (2010) in broiler chicken also reported similar findings. In contrast to these findings, Shamsa et al. (2013) reported increased $(\mathrm{P}<0.05)$ serum albumin content in broiler chicken fed diets containing $4 \%$ garlic powder as compared to the control.

\section{Effect on serum globulin}

Increased levels of inclusion of dried garlic powder from 0 to $2 \%$ in the diet had no effect $(\mathrm{P}>0.05)$ on serum 
globulin content ( $\mathrm{mg} / \mathrm{dl})$ of quails (Table 2). In line with the present findings, Fadlalla et al. (2010) reported that feeding graded levels of garlic up to $0.6 \%$ level in the diet of broilers had no effect $(\mathrm{P}>0.05)$ on serum globulin content while Onu (2010) reported that feeding garlic at $0.25 \%$ level in the diet of finisher broilers had no effect $(\mathrm{P}>0.05)$ on serum globulin content. Similar findings were reported by Motamedi and Taklimi (2014) in laying hens.

\section{Effect on serum glucose}

The serum glucose content ( $\mathrm{mg} / \mathrm{dl}$ ) decreased significantly $(\mathrm{P}<0.01)$ with increased levels of dried garlic powder from 0 to $2.0 \%$ in the diet of quails (Table 3 ). These results agree with the findings of Shamsa et al. (2013) who reported a significant decrease $(\mathrm{P}<0.05)$ in serum glucose concentration in broilers when fed $4 \%$ garlic in the diet as compared to the control. However, several researchers reported no effect $(\mathrm{P}>0.05)$ on serum glucose concentration in broiler chicken (Horton et al., 1991; Canogullari et al., 2010; Kim, 2010) and turkey hens (Krauze et al., 2012) upon feeding dried garlic powder in the diet.

\section{Effect on serum triglycerides}

The serum triglyceride content $(\mathrm{mg} / \mathrm{dl})$ of quails decreased significantly $(\mathrm{P}<0.01)$ with inclusion of dried garlic powder up to $2.0 \%$ in the diet (Table 3 ). These results agree with the findings of Ademola et al. (2009) who reported that supplementation of dried garlic powder at 1.0, 1.5 and 2.0 $\%$ in the diet had resulted in significant decrease $(\mathrm{P}<0.01)$ in serum triglyceride content of broilers. The decreased serum triglyceride content observed in quails upon feeding dried garlic powder in the diet might probably be due to the possible mechanism of allicin, the organosulfur component of garlic, combining with the - $\mathrm{SH}$ group (Cavallito et al., 1944), the functional part of CoA, which is necessary for the biosynthesis of triglycerides. Binding of allicin to the enzyme is non-covalent and reversible in nature. Inhibition of fatty acid and lipid formation by allicin may be a basis for hypo-cholesterolaemic and hypolipidemic action of garlic (Focke et al., 1990).

Similarly, Yalcin et al. (2006), Dehkordi et al. (2009), Prasad et al. (2009), and Issa and Omar (2012) reported significantly decreased serum triglyceride content in broiler chicken upon feeding dried garlic powder in the diet. However, some researchers (Canogullari et al., 2010; Kim, 2010; Amouzmehr et al., 2012; Puvaca et al., 2014; Brzoska et al., 2015) reported that feeding dried garlic powder in the diet had no effect $(\mathrm{P}>0.05)$ on serum triglyceride content in broiler chicken.

\section{Effect on serum total cholesterol}

The serum total cholesterol content $(\mathrm{mg} / \mathrm{dl})$ decreased significantly $(\mathrm{P}<0.01)$ with increased level of incorporation of dried garlic powder from 0 to $2.0 \%$ in the diet of quails (Table 3). Similarly, Ademola et al. (2009) reported that supplementation of dried garlic powder up to 2.0 $\%$ in the diet resulted in decreased $(\mathrm{P}<0.01)$ serum total cholesterol content in broilers. The decrease in the serum cholesterol levels observed could be attributed to the hypo-cholesterolaemic and hypolipidemic action of garlic products which depresses the hepatic activities of lipogenic and cholesterogenic enzymes such as malic enzyme, fatty acid synthase, glucose-6-phosphatase dehydrogenase (Qureshi et al.,1983a) and 3-hydroxy-3-methyl-glutarylCoA (HMG-CoA) reductase (Qureshi et al.,1983b). In corroboration, several researchers reported that inclusion of dried garlic powder resulted in significantly decreased serum total cholesterol content in broiler chicken (Yalcin et al., 2006; Safaa, 2007; Khan et al., 2007; Dehkordi et al., 2009; Prasad et al., 2009; Kim, 2010; Ao et al., 2010; Issa and Omar, 2012) and laying quails (Canogullari et al., 2010).

\section{Effect on HDL cholesterol}

The serum HDL cholesterol content $(\mathrm{mg} / \mathrm{dl})$ of quails increased significantly $(\mathrm{P}<0.01)$ with increased level of dried garlic powder from 0 to $2.0 \%$ in the diet (Table 3 ). In line with the present findings, Ademola et al. (2009) reported that feeding garlic at 1.0, 1.5 and $2.0 \%$ level in the diet resulted in increased $(\mathrm{P}<0.01)$ serum HDL cholesterol concentration in broiler chicks. The increased serum HDL content observed in quails upon feeding dried garlic powder in the diet might be attributed to the significant hypo-lipidemic effect resulting in lowering the total cholesterol levels and triglycerides and thus increasing the levels of high-density lipoprotein. Similarly, increased serum HDL cholesterol levels upon feeding garlic in the diet were also reported earlier (Safaa, 2007; Prasad et al., 2009; Kim, 2010; Canogullari et al., 2010; Issa and Omar, 2012; Puvaca et al., 2014). 


\section{Effect on LDL cholesterol}

Serum LDL cholesterol content $(\mathrm{mg} / \mathrm{dl})$ decreased significantly $(\mathrm{P}<0.01)$ with increased level of dried garlic powder from 0 to $2.0 \%$ in the diet of quails (Table 3 ). The decreased serum LDL content observed in quails upon feeding dried garlic powder in the diet may probably be due to the possible mechanism of antioxidant and antiperoxide lowering action of garlic products i.e. S-allyl Cysteine Sulfoxide (SAC) on LDL-C or decrease in hepatic production of VLDL-C which serves as the precursor of LDL-C in the blood circulation (Grundy, 1986). In line with these findings, several researchers reported that inclusion of dried garlic powder resulted in significantly decreased serum LDL cholesterol (Safaa, 2007; Khan et al., 2007; Ademola et al., 2009; Prasad et al., 2009; Kim, 2010; Issa and Omar, 2012; Puvaca et al., 2014) in broiler chicken and Canogullari et al., 2009; and Motamedi and Taklimi (2014) in laying hens. In contradiction, Canogullari et al. (2010) reported significantly increased serum LDL cholesterol in laying quails fed garlic powder in the diets.

\section{Effect on VLDL cholesterol}

The serum VLDL cholesterol content $(\mathrm{mg} / \mathrm{dl})$ of quails decreased significantly $(\mathrm{P}<0.01)$ with increased level of dried garlic powder up to $2.0 \%$ in the diet (Table 3 ). Prasad et al. (2009) reported that supplementation of dried garlic powder at $0,1.5$ and $3.0 \%$ in the diet had resulted in significant decrease $(\mathrm{P}<0.01)$ in serum VLDL cholesterol content of broilers. The possible mechanism of lowering VLDL cholesterol by garlic products is unclear. However, it may probably be attributed to the increase in the esterified cholesterol by garlic supplementation which may be a result of decreased production or increased excretion of esterified cholesterol through bile (Girish Kumar et al., 1998). This might have resulted in significant decrease $(\mathrm{P}<0.01)$ in VLDL cholesterol concentration in quails.

\section{Effect on serum creatinine}

The serum creatinine content decreased $(\mathrm{P}<0.01)$ with increased level of dried garlic powder from 0 to $2.0 \%$ in the diet of quails (Table 3). Reddy et al. (2018) reported that feeding coriander as natural feed additives in the diet of quails resulted in decreased serum creatinine content in Japanese quails. Significant increase in serum uric acid and creatinine levels are indicative of nephrotoxicity in broiler chickens (Huff et al., 1988). Thus, the decreased $(\mathrm{P}<0.01)$ serum creatinine content observed indicate improved kidney health in terms of filtration rate which may be attributed to the incorporation of dried garlic powder in the diet. In contradiction, Krauze et al. (2012) reported that creatinine levels showed a significant $(\mathrm{P}<0.01)$ increase in turkey chicken fed garlic powder in the diet while several authors (Onu, 2010; Onyimonyi et al., 2012; Gerzilov et al., 2015) reported no effect $(\mathrm{P}>0.05)$ on serum creatinine content in broiler chicken.

\section{CONCLUSION}

It is concluded that inclusion of dried garlic powder up to $2.0 \%$ level in diet resulted in decreased serum glucose, triglyceride and total cholesterol, LDL cholesterol content and increased the HDL cholesterol content in quails indicating that garlic is very effective in regulation of lipid metabolism in a favorable manner.

\section{ACKNOWLEDGEMENTS}

The authors are thankful to Sri Venkateswara Veterinary University, Tirupati, India for providing necessary facilities for conducting the research work. The first author is thankful to Department of Animal Husbandry, Government of Andhra Pradesh for providing an opportunity to pursue Master degree.

\section{REFERENCES}

Ademola, S.G., Farrinu, G.O. and Babatunde, G.M. 2009. Serum lipid, growth and haematological parameters of broilers fed garlic. World J. Agric. Sci., 5: 99-104.

Amouzmehr, A., Behrouz, D., Jalil, G.N., Kyung II, S., Jayant, L. and Fereidoum, F. 2012. Effects of garlic and thyme extracts on growth performance and carcass characteristics of broiler chicks. J. Anim. Sci. Technol., 54: 185-190.

Ao, X., Yoo, J.S., Lee, J.H., Jang, H.D., Wang, J.P., Zhou, T.X. and Kim, I.H. 2010. Effects of fermented garlic powder on production performance, egg quality, blood profiles and fatty acids composition of egg yolk in laying hens. Asian-Aust $J$. Anim. Sci., 23(6): 786-791.

Brzoska, F., Bogdan, S., Olga, M.R. and Jozef, S. 2015. The effect of garlic (Allium sativum L.) on growth performance, mortality rate, meat and blood parameters in broilers. Ann. Anim. Sci., 15(4): 961-975. 
Canogullari, S., Baylan, M., Erdogan, Z., Duzguner, V. and Kucukgul, A. 2010. The effect of dietary garlic powder on performance, egg yolk and serum cholesterol concentration in laying quails. Czech J. Anim. Sci., 55: 286-293.

Canogullari, S., Karaman, M., Erdogan, Z., Baylan, M., Kucukgul, A., Duzguner, V. and Ozugur, A. 2009. Effect of garlic powder on egg yolk and serum cholesterol on performance of laying hens. Bull Vet Pula Wy., 53: 515-519.

Cavallito, C.J., Buck, J.S. and Suter, C.M. 1944. Allicin, the antibacterial principle of Allium sativum. Determination of the chemical composition. J. Am. Chem. Soc., 66: 1952-1954.

Dehkordi, S.H., Moghadam, A.Z., Negahdar, M., Ehsan, A., Razieh, G. and Ehsan, D. 2009. The effects of fresh garlic on the serum concentration of total cholesterol, total triglyceride and adipose tissues of broilers. Comp. Clin. Path., 19: 363365 .

Duncan, D.B. 1955. Multiple range and multiple F-tests. Biometrics, 11: 1-42.

Fadlalla, I.M.T., Mohammad, B.H. and Bakhiet, A.O. 2010. Effect of feeding garlic on the performance and immunity of broilers. Asian J. Poult. Sci., 4: 182-189.

Focke, M.A., Feld Lichtenthaler, K. 1990. Allicin: A naturally occurring antibiotic from garlic, specifically inhibits acetyl coA synthetase. FEBS-Lett., 261: 106-108.

Gerzilov, V., Aleksander, N., Petar, P., Nadya, B., George, P. and Atanas, B. 2015. Effect of dietary herbal mixer supplement on growth performance and egg production and health status in chickens. J. Cen. Eur. Agric., 16(2): 10-27.

Girish Kumar, V., Jaya Prakash, K.P., Surendranathan and Narendranath, R. 1998. Effect of Allium cepa Linn. and Allium sativum Linn. on plasma free, esterified and lipoprotein cholesterol in Japanese quails (Coturnix coturnix japonica). Indian J. Poult. Sci., 33: 142-148.

Grundy, S.M. 1986. Cholesterol and coronary heart disease: A new era. J. Am. Med. Assoc., 256: 2849-2859.

Horton, G.M.J., Fennell, M.J. and Prasad, B.M. 1991. Effect of dietary garlic (Allium sativum) on performance, carcass composition and blood chemistry changes in broiler chickens. Can. J. Anim. Sci., 71: 939-942.

Huff, W.E., Kubena, L.F. and Harvey, R.B. 1988. Progression of ochratoxicosis in broiler chickens. Poult. Sci., 67: 1139-1146.

ICAR, 2013. Indian council of Agricultural Research. Nutrient requirements of poultry, New Delhi.

Issa, K.J. and Omar, J.M.A. 2012. Effects of garlic powder on performance and lipid profile of broilers. Open J. Anim. Sci., 2: $62-68$.

Khan, S.H., Rozina, S. and Mohammad, A.A. 2007. Effects of dietary garlic on performance and serum and egg yolk cholesterol concentration in laying hens. Asian J. Poult. Sci.,
1(1): 22-27.

Kim, Y.J. 2010. Effects of dietary supplementation of garlic by-products on performance and carcass characteristic of chicken meat. Korean J. Poult. Sci., 37(3): 221 - 228.

Krauze, M., Malzina, M., Gryzinska M, Strachecka A. 2012. Effect of garlic (Allium sativum) on selected indices of blood metabolic profile and rearing efficiency of turkey hens. Annales Universitatis Mariae Curie-Sklodowska, LublinPolonia, 3: 48-59.

Mayo, J.L. 1997. Dietary influences on cardiovascular disease and female cancer risk. Clin. Nutr. Insights., 5: 1-4.

Motamedi, S.M. and Taklimi, S.M.M. 2014. Investigating the effect of fenugreek seed powder and garlic powder in the diet on immune response of commercial laying hen egg. Ind. $J$. Sci. Res., 3(1): 277-283.

Onu, P.N. 2010. Evaluation of two herbal spices as feed additives for finisher broilers. Biotechnol. Anim. Husb., 26: 383-392.

Onyimonyi, A.E., Chukwuma, P.C. and Igbokwc, C. 2012. Growth and hypo-cholesterolemic properties of dry garlic (Allium sativum) on broilers. Afr. J. Biotechnol., 11: 26662671.

Prasad, R., Rose, M.K., Virmani, M., Garg, S.L. and Puri, J.P. 2009. Lipid profile of chicken (Gallus domesticus) in response to dietary supplementation of garlic. Int. J. Poult. Sci., 8: 270-276.

Puvaca, N., Kostadinovic, L.J., Ljubojevic, D., Lukac, D., Popovic, S., Dokmanovc, B. and Stanacev, V. 2014. Effects of dietary garlic addition on productive performance and blood lipid profile of broiler chickens. Biotech. Anim. Husbandry., 30(4): 669-676.

Qureshi, A.A., Abuirmeileh, N., Din, Z.Z., Elson, C.E. and Burger, W.C. 1983a. Inhibition of cholesterol and fatty acid biosynthesis in liver enzymes and chicken hepatocytes by polar fractions of garlic. Lipids., 18: 343-348.

Qureshi, A.A., Din, Z.Z., Auirmeileh, N., Burger, W.C., Ahmad, Y. and Elson, C.E. 1983b. suppression of avian hepatic lipid metabolism by solvent extracts of garlic: Impact on serum lipids. J. Nutr., 113: 1746-1755.

Reddy, N.B.C., Kumar, D.S., Kishore, K.R. and Kumari, K.N.R. 2018. Effect of incorporation of coriander seed meal at varying levels on serum biochemical profile in Japanese quail diets. J. Anim. Feed Sci. Tech., 6: 9-14.

Safaa, H. 2007. Effect of dietary garlic or fenugreek on cholesterol metabolism in laying hens. Egyptian Poult. Sci., 27(4): 1207-1221.

Shamsa, T.M., Naqi Al-bayati, T.M. and Ibrheem, I. 2013. The effects of garlic and Nigella sativa on some biochemical and production characteristic in broiler chicken. Kufa J. Vet. Med. Sci., 4(1): 75-80. 
Snedecor, G.W. and Cochran, W.G. 1994. Statistical methods. $9^{\text {th }}$ ed. Iowa State University press, IOWA, USA.

SPSS. 2008. Statistical packages for Social Sciences, Version 17.0, SPSS Inc., Illinois, USA.

Stanacev, V., Glamocic, D., Milosevic, N., Puvaca, N., Stanacev, V. and Plavsa, N. 2011. Effect of garlic (Allium sativum l.) in fattening chicks nutrition. Afr. J. Agric. Res., 6: 943-948.
Yalcin, S., Onbasilar, I., Sehu, A. and Yalcin, S. 2007. The effects of dietary garlic powder on the performance, egg traits and blood serum cholesterol of laying hens. Asian-Australs $J$. Anim. Sci., 20: 944-947. 
